\title{
Dendritic growth of DAPI-accumulating amacrine cells in the retina of the goldfish
}

\author{
Ronald N. Brown Jr. and Peter F. Hitchcock \\ The University of Michigan School of Medicine, Departments of Ophthalmology and Anatomy and Cell Biology, Ann Arbor, \\ MI 48105 (U.S.A.)
}

(Accepted 23 May 1989)

Key words: Lucifer yellow; Dendrite; Plasticity; Synapse; Intracellular injection

\begin{abstract}
The dendritic growth of amacrine cells was studied in the retina of the goldfish. Those cells that accumulated the intraocularly injected fluorescent dye 4,6-diamidino-2-phenylindole (DAPI) were compared in retinal wholemounts from small and large animals. Dendritic arbors were stained by intracellular injections of Lucifer yellow. Based upon their dendritic morphology, two types were identified, radiate and fusiform. The dendritic field areas and the number of dendritic terminals were quantitatively compared for cells in small retinas from young fish and large retinas from old fish in the region of the retina that grows by expansion. For both cell types the dendritic fields were significantly larger in the large retinas. The radiate cells had the same number of dendritic terminals in retinas of both sizes, whereas the fusiform cells in the large retinas had significantly more dendritic terminals than those in the small retinas. This resulted from the addition of new dendrites to the proximal arbor. These data show that with retinal expansion the pattern of dendritic growth by a amacrine cells is cell-type specific.
\end{abstract}

\section{INTRODUCTION}

The formation of synaptic contacts in the developing central nervous system requires the coordinated apposition of pre- and postsynaptic processes that is reflected in changes in the morphology of both synaptic partners. Investigating these structural changes and inferring the underlying cellular events should lead to insights concerning both process outgrowth and synapse formation.

The fish retina is an appropriate tissue for studying the structural changes associated with synaptogenesis, because it grows throughout the animal's life by a continual neurogenesis at the margin ${ }^{11,12,18,19,23}$ and by a uniform, balloon-like expansion ${ }^{4,13}$. In central retinal there is continual synaptogenesis in the absence of neurogenesis within the inner plexiform layer 5 (IPL), a neuropil in which the neurons of the inner nuclear layer (bipolar, amacrine, and interplexiform cells) contact each other and the ganglion cells.

Recent studies have described the changes in the dendritic arbors of bipolar and ganglion cells in the growing retina of the goldfish ${ }^{10,14}$. The present study sought to determine the growth related structural changes that occur in the dendrites of amacrine cells, and to relate this to the ongoing snyapse formation by this class of retinal interneuron.

The dendritic growth of amacrine cells that accumulated the nucleic acid binding molecule 4,6diamidino-2-phenylindole (DAPI) ${ }^{17}$ were studied. Comparisons were made between cells in the central retina of small (young) and large (old) fish. It was assumed that this was equivalent to sampling two time points, early and late, during the development of these cells.

Some of these results appeared previously in an abstract ${ }^{3}$.

Correspondence: P.F. Hitchcock, The University of Michigan, Department of Ophthalmology, W.K. Kellogg Eye Center, 1000 Wall Street, Ann Arbor, MI 48105, (U.S.A.) 


\section{MATERIALS AND METHODS}

Common goldfish (Carassius auratus) were obtained from Grassyfork Fisheries (Martinsville, IN), and maintained at $18-20{ }^{\circ} \mathrm{C}$ in aerated, artificial pond water ${ }^{1}$ in 10 gallon aquaria.

Five goldfish (10 retinas) were used: 3 small ones (6.5-9.3 cm standard length; $2.8-3.0 \mathrm{~mm}$ lens diameter), and two large ones (16.5-18 cm standard length; 4.2-4.3 mm lens diameter). All fish were deeply anesthetized with tricaine methanesulfonate (MS 222), and intraocular injections of DAPI at an initial concentration of $2 \mathrm{~g} /$ liter were made in both eyes using a Hamilton microliter syringe with a 30 gauge needle. Seven and $10 \mu \mathrm{l}$ were injected into the eyes of the small and large fish, respectively. Twenty-four hours later, the fish were dark-adapted for at least $1 \mathrm{~h}$, reanesthetized, and the retinas were isolated as described previously ${ }^{10}$. The isolated retinas were fixed for $45 \mathrm{~min}$ in fresh, room temperature $2 \%$ paraformaldehyde $/ 0.01 \%$ glutaraldehyde in $0.1 \mathrm{M}$ phosphate buffer, $\mathrm{pH}$ 7.4. After fixation, the retinas were rinsed $3 \times 10 \mathrm{~min}$ in buffer, transferred, ganglion-cell sided up, to a circular piece of non-fluorescent filter paper (Schleicher and Scheull; cat. no. 05710), which provided mechanical support, and the vitreous was gently brushed away.

The dendritic arbors of amacrine cells that were labeled by the DAPI (see below) were stained by intracellular injections of Lucifer yellow $\mathrm{CH}$ (LY; Sigma) using the technique of Tauchi and Masland ${ }^{25}$. 2t. The filter paper/retina was placed in a plexiglas chamber that was clamped to the stage of a fluorescence microscope modified for intracellular injections. The tips of micropipettes, with a resistance of 100-140 M $\Omega$ (filled with $0.1 \mathrm{M}$ phosphate buffer) were filled with $3 \%$ aqueous LY and back-filled with $0.25 \mathrm{M} \mathrm{KCl}$ in $0.05 \mathrm{M}$ Tris- $\mathrm{HCl}$ buffer, $\mathrm{pH} 7.4$. Electrodes were visually guided to DAPI-labeled cells with a micromanipulator attached to the stage of the microscope. When the electrode made contact with the cell, its membrane was penetrated by modulating the capacity compensation circuit (buzzing) of the amplifier. At all times, the retinas were covered with a thin film of phosphate buffer. LY was iontophoretically ejected for approximately 5 min with a negative current of 2-10 nA pulsed in a square wave of $100 \mathrm{~ms}$ duration at $4 \mathrm{~Hz}$. Each cell was photographed and traced with a drawing tube.

Dendritic field areas were computed by measuring the diameter of the dendritic field through its longest axis and along a line orthogonal to this axis, averaging the values, and calculating the area of an equivalent circle. Dendritic 'complexity' was assessed by counting the number of terminals on the arbor of each cell. These included the terminations of both dendrites and small dendritic appendages. In addition, for each fusiform cell (see below) the relative position of each terminal within the arbor was determined. The tracing of each cell was overlaid with a template, centered on the soma, that divided the arbor into five concentric zones. The

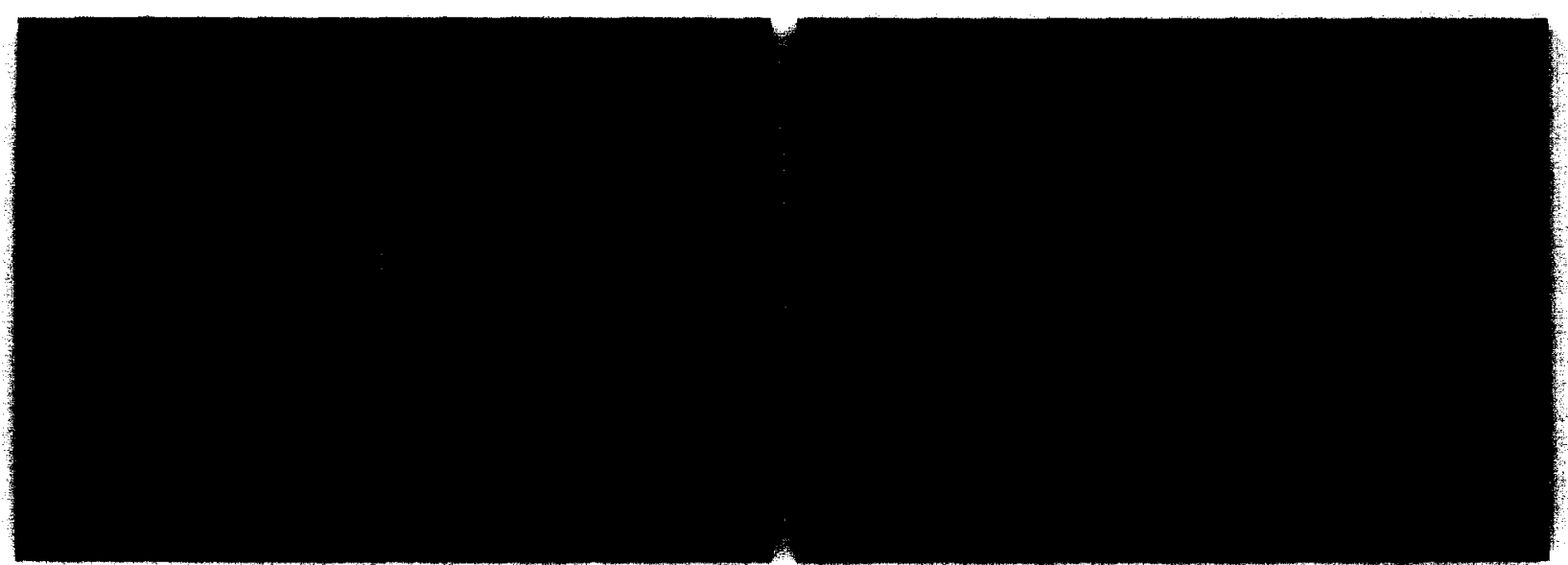

Fig. 1. Fluorescence photomicrographs of LY-filled amacrine cells that accumulated DAPI. A: radiate cell. B: fusiform cell. Bar $=50 \mu \mathrm{m}$. 
template was scaled such that each zone enclosed $20 \%$ of the radius of each cell's dendritic field. The number of terminals in each zone was then counted.

The data described below are from 36 cells from the small retinas and 24 cells from the large retinas. All cells were located in central retina, midway between the optic disc and the retinal margin, which generally corresponds to the location that Fisher and Easter ${ }^{5}$ studied. Earlier studies have shown that this region of the retina grows by stretch only (e.g. ref. $13)$.

Statistical analyses were made using the MannWhitney $U$-test ${ }^{15}$.
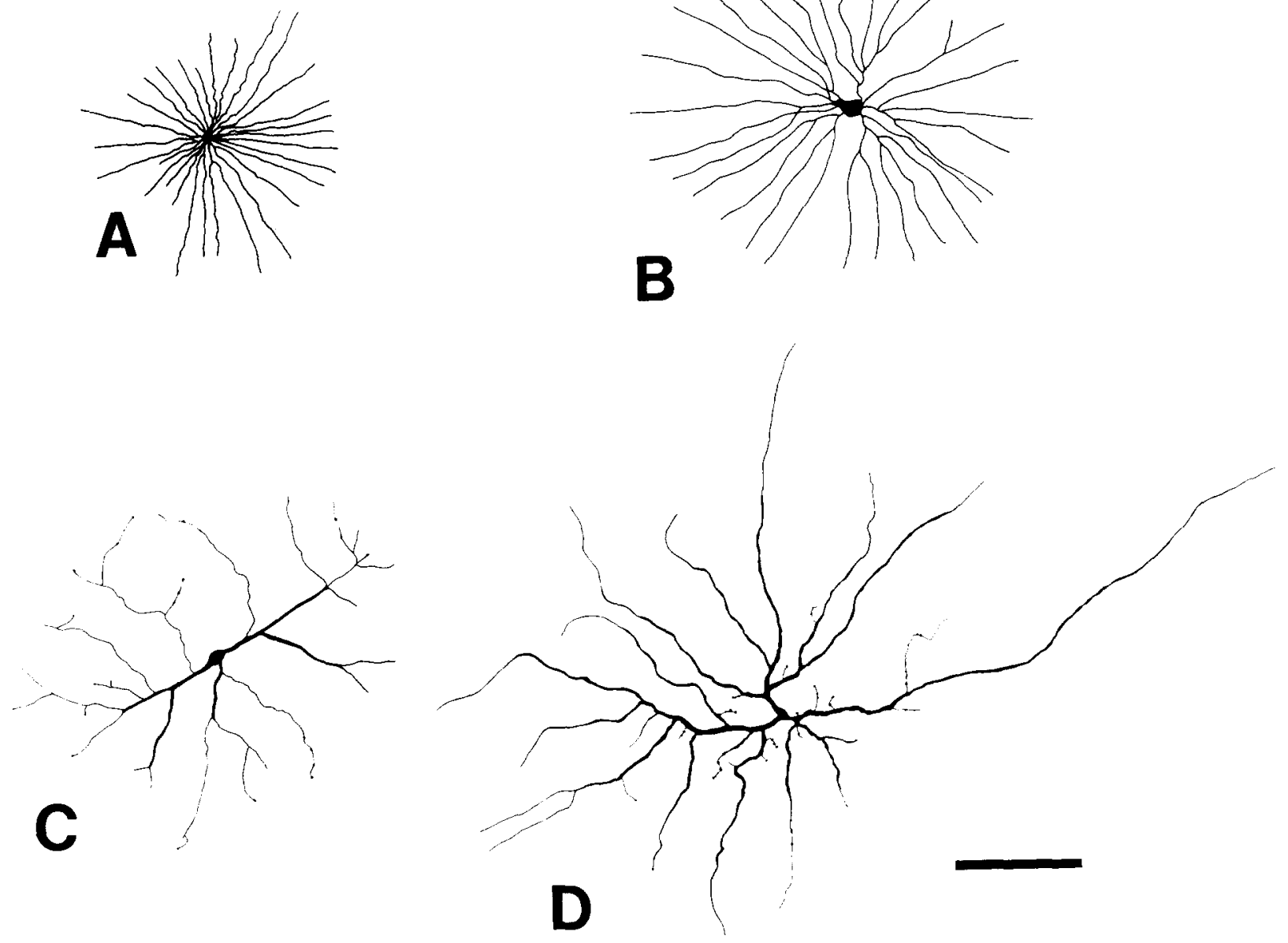

\section{RESULTS}

Intraocular injections of DAPI in goldfish resulted in specific uptake by presumed amacrine cells and a more diffuse background staining pattern. The background consisted of faint staining of the ganglion cells, and particulate staining in the IPL. The background staining did not obscure the specific staining (see below), and it was useful for identifying the proximal/distal zones in the IPL. The presence of the background staining is assumed to be due to a slightly greater than optimal intraocular concentration of the DAPI ${ }^{17}$. The specific staining was more intensely fluorescent than the background, and it

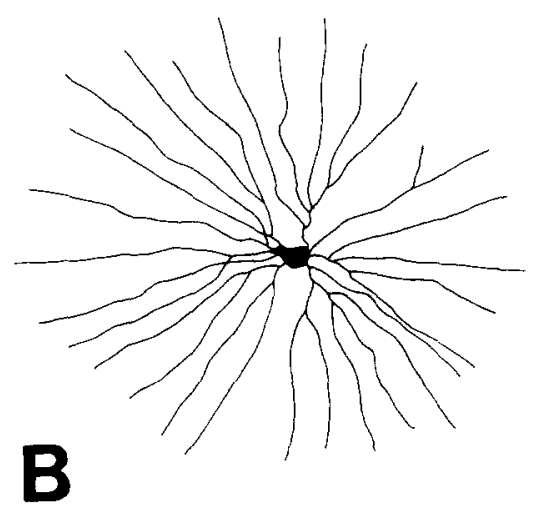

Fig. 2. Drawings of LY-filled amacrine cells that accumulated DAPI. Cells A and B are radiate cells from the retina of a small and large fish, respectively. Cells $C$ and $D$ are fusiform cells from the retina of a small and large fish, respectively. Note the greater number of dendrites on the proximal arbor of cell D. Bar $=200 \mu \mathrm{m}$. 
TABLE 1

Dendritic field areas of DAPI-accumulating amacrine cells in small and large retinas

Dendritic field areas of both cell types were significantly larger in the large retinas than in the small ones (Mann-Whitney $U$-test, $P<0.05)$.

$\begin{array}{lll}\text { Cell type } & \text { Small retinas } & \text { Large retinas } \\ \text { Radiate } & 0.09 \pm 0.05 \mathrm{~mm}^{2} & 0.2 \pm 0.1 \mathrm{~mm}^{2} \\ \text { Fusiform } & 0.09 \pm 0.04 \mathrm{~mm}^{2} & 0.3 \pm 0.1 \mathrm{~mm}^{2}\end{array}$

was confined to somata lying along the border between the IPL and the inner nuclear layer (INL). It is assumed that these intensely stained cells actively accumulated the dye ${ }^{17}$.

Intracellular staining of the DAPI-accumulating neurons within the INL revealed two cell types that had distinctly different dendritic morphologies. Fig. $1 \mathrm{~A}$ illustrates one type, called the radiate cell, that characteristically had a round soma, primary dendrites that branched near the soma, and long, straight, radially oriented higher order dendrites that formed circular or slightly ovoid fields. Occasionally the distal dendritic processes branched as well. The dendritic arbors of these cells were planar and confined to the inner half of the IPL.

Fig. 1B illustrates the second type, called the fusiform cell. It was characterized by a fusiform soma, and 2-3 very thick, smooth primary dendrites that branched relatively frequently and had numerous en passant and terminal swellings. The arbors of these cells were also located in the inner half of the IPL, although they were not as strictly planar as the radiate cells.

Comparing cells from the retinas of small fish with those from large ones revealed two consistent differences, illustrated in Fig. 2. First, as anticipated (see ref. 10) the somata, dendrites, and dendritic fields were larger for cells in the large retinas than in the small. In the larger retinas, the areas of the dendritic fields of the radiate cells were about twice as large as their counterparts in the small retinas, and the dendritic fields of the fusiform cells enlarged about 3 times (Table I). Second, the number of dendritic terminals was unchanged for the radiate cells, but the number of terminals was significantly greater for fusiform cells in the large retinas than for those in the small ones (Table II). These results
TABLE II

Total number of dendritic terminals found on DAPI-accumulating amacrine cells in small and large retinas

The asterisk denotes values that are significantly different between the small and large retinas (Mann-Whitney $U$-test, $P$ $<0.01)$.

$\begin{array}{lcc}\text { Cell type } & \text { Small retinas } & \text { Large retinas } \\ \text { Radiate } & 25.4 \pm 3.2 & 26.5 \pm 4.1 \\ \text { Fusiform } & 23.9 \pm 8.0 & 35.6 \pm 11.5^{*}\end{array}$

suggested that with retinal expansion, the arbors of the radiate cells enlarged by interstitial growth only, whereas the fusiform cells grew both interstitially and by elaborating new dendrites.

The fusiform cells in the large retinas appeared to have more thin, beaded processes that were located on the proximal arbor (i.e. near the soma) than cells in the small retinas (cf. Fig. 2C,D). This was confirmed quantitatively. Fig. 3 illustrates the average number of dendritic terminals per fusiform cell plotted as a function of the radial distance from the soma (see Materials and Methods). This graph shows that the average fusiform cell in the large retinas had significantly more dendritic terminals, and therefore more dendrites, in the proximal regions of the dendritic field. Further, the fusiform cells from small and large retinas had a similar number of primary dendrites ( $3.1 \pm 0.8$ for both),

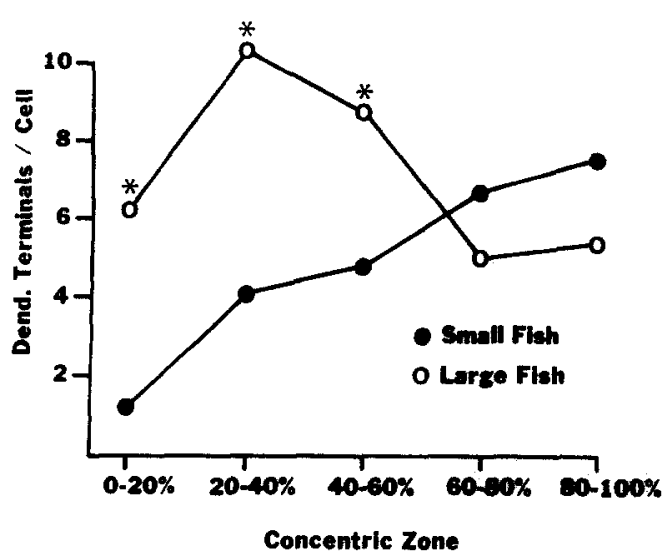

Fig. 3. Graph of the number of dendritic terminals found on fusiform cells vs the percent distance from the soma (see text for details). Open and filled circles correspond to values from cells in large and small fish, respectively. Asterisks denote points where the values are significantly different (MannWhitney $U$-test; $P<0.01$ ). 
indicating that the new dendrites arose from existing ones.

\section{DISCUSSION}

The present study showed that in the goldfish retina, intraocular DAPI is accumulated by two classes of amacrine cells, radiate and fusiform. The radiate cell had radially oriented dendrites that branched infrequently to form round or ovoid dendritic fields, and the fusiform cell had thick dendrites that branched relatively frequently to form oval dendritic fields. Amacrine cells with similar morphologies have been described following intracellular recording and dye filling in $\operatorname{carp}^{24}$, and following Golgi procedures in the catfish ${ }^{20}$ and roach ${ }^{28}$.

Masland et al. ${ }^{17}$ demonstrated that in the rabbit retina cholinergic amacrine cells are labeled by DAPI. We have no independent evidence to suggest that the DAPI-accumulating neurons in the goldfish are cholinergic, and an immunocytochemical study by Tumosa et al. ${ }^{27}$ suggests that the amacrine cells described here and those that contain the acetylcholine synthesizing enzyme choline acetyltransferase (ChAT; see also ref. 16) have different morphologies. Regardless of their biochemical characteristics, the uptake of DAPI by the two types of amacrine cells described here was useful for studying the dendritic growth of this class of retinal neuron.

Quantitative comparisons of cells in small and large retinas showed that the dendritic arbors of both types of amacrine cells grew interstitially; their dendrites grew in girth and length (see Fig. 2), and, in addition, the fusiform cells become more complex by adding new dendrites to the proximal arbor. This growth is similar to that of two other classes of retinal neurons in the goldfish. The dendrites of ganglion cells grow interstitially only ${ }^{2,9,10}$, whereas the dendrites of bioplar cells grow interstitially and add new dendritic branches ${ }^{14}$. It was suggested that interstitial growth of ganglion cell dendrites resulted from stretching forces imposed upon them by the expanding retina ${ }^{10}$. A similar mechanism could explain the interstitial growth of the amacrine cells described here, although it is insufficient to account for the elaboration of new dendrites by the fusiform cells. The outgrowth of new dendrites could be explained if some amacrine cells seek at all times to enlarge their dendritic territories, and the expansion of the retina reduces the forces that act to constrain dendritic growth ${ }^{7,21}$.

As the goldfish retina enlarges by expansion there is an increase in the planimetric density (number $/ \mu \mathrm{m}^{2}$ of retinal surface) of amacrine cell synapses found within central retina ${ }^{5}$. Assuming that all amacrine cells in the goldfish retina participate in this continuing synaptogenesis, the correlation between synapse addition and dendritic growth suggests that with retinal growth amacrine cells can insert new presynaptic elements into the membrane of existing dendrites and/or grow new presynaptic processes.

An important question raised by these results is how the number of synapses created by an amacrine cell is regulated. Data from studies of the peripheral nervous system (PNS) suggest that synapse formation by amacrine cells could be regulated by their postsynaptic targets. In the PNS, the surface area of the postsynaptic cell determines the number and convergence of synaptic contacts it receives ${ }^{6.22}$. For example, in the cardiac ganglion of Xenopus, there is a positive, linear relationship between surface area of the neurons and the number of synaptic boutons that contact them, and the frequency distribution of boutons per cell suggests that soma size is the only factor that influences the number of boutons it receives ${ }^{22}$. Perhaps via similar mechanisms, the synapses formed by an amacrine cell in the goldfish are regulated by the size of its postsynaptic target, which enlarges with retinal expansion as well ${ }^{10}$. Current data suggest that the maintenance of synaptic contacts from amacrine cells onto their targets depends upon interactions between the two ${ }^{8,29}$. Whether or not these interactions regulate the formation of synapses by amacrine cells remains to be determined.

\section{ACKNOWLEDGEMENTS}

We thank Drs. P. Raymond and S.S. Easter Jr. for useful comments on an earlier version of the manuscsript, A. Ozobia and M. Gillett for technical assistance, and D. Giebel for secretarial assistance. This work was supported by Grants T32-EY07022 to R.N.B., and BNS-8607886, EYO7060, and EY07003 (CORE) to P.F.H. 


\section{REFERENCES}

1 Allee, W.C., Kinel, A.J. and Hoskins, W.H., The growth of goldfish in homotypically conditioned water; a population study in mass physiology, J. Exp. Zool, 84 (1940) 417-443.

2 Bloomfield, S.A. and Hitchcock, P.F., Dendritic arbors of large field ganglion cells are scaled both morphologically and electronically during retinal expansion in the goldfish, Invest. Ophthalmol. Vis. Sci., Suppl., 30 (1989) 345.

3 Brown, R. and Hitchcock, P.F., Morphology and growth of DAPI-accumulating amacrine cells in the retina of the goldfish. Invest. Ophthalmol. Vis. Sci. Suppl., 30 (1989) 345.

4 Easter Jr., S.S., Johns, P.R. and Baumann, L.R., Growth of the adult goldfish eye. I: Optics, Vision Res., 17 (1977) 469-477.

5 Fisher, L.J. and Easter Jr., S.S., Retinal synaptic arrays: continuing development in the adult goldfish, J. Comp. Neurol., 185 (1979) 373-379.

6 Forehand, C.J., Density of somatic innervation on mammalian autonomic ganglion cells is inversely related to dendritic complexity and pre-ganglionic convergence, $J$. Neurosci., 5 (1985) 3404-3408.

7 Hitchcock, P.F., Exclusionary dendritic interactions in the retina of the goldfish, Development, in press.

8 Hitchcock, P.F., The death of ganglion cells results in selective synapse loss in the inner plexiform layer of the goldfish's retina, Invest. Ophthalmol. Vis. Sci., Suppl., 30 (1989) 345 .

9 Hitchcock, P.F., Constant dendritic coverage by ganglion cells with growth of the goldfish's retina, Vision Res., 27 (1987) 17-22.

10 Hitchcock, P.F. and Easter Jr., S.S., Retinal ganglion cells in goldfish: qualitative classification into four morphological types, and a quantitative study of the development of one of them, J. Neurosci., 6 (1986) 1037-1050.

11 Johns, P.R., Growth of the adult goldfish eye. III. Source of the new retinal cells, $J$. Comp. Neurol., 176 (1977) 343-358.

12 Johns, P.R. and Easter Jr., S.S., Growth of the adult goldfish eye. II. Increase in retinal cell number, J. Comp. Neurol., 176 (1977) 331-342.

13 Kock, J.H., Neuronal addition and retinal expansion during growth of the crucian carp eye, J. Comp. Neurol., 209 (1982) 275-286.

14 Kock, J.H. and Stell, W.K., Formation of new rod photoreceptor synapses onto differentiated bipolar cells in goldfish retina, Anat. Rec., 211 (1985) 69-74.
15 Krauth, J., The interpretation of significance tests for independent and dependent samples, $J$. Neurosci. Methods, 211 (1985) 269-281.

16 Marc, R.F., Neurochemical stratification in the inner plexiform layer of the vertebrate retina, Vision Res., 26 (1986) 223-238.

17 Masland, R.H., Mills, J.W. and Hayden, S.A., Acetylcholine-synthesizing amacrine cells: identification and selective staining by using radioauthography and fluorescent markers, Proc. R. Soc. Lond. Ser. B, 223 (1984) 79-100.

18 Meyer, R.L., Evidence from thymidine labeling for continuing growth of retina and tectum in juvenile goldfish, Exp. Neurol., 59 (1978) 99-111.

19 Müller, H., Bau und Wachtum der Netzhaut des Guppy (Lebistes reticulatus), Zool. Jb. Abt. Allg. Zool. Physiol., 63 (1952) 275-234.

20 Naka, K.-I. and Carraway, N.R.G., Morphological and functional identification of catfish retinal neurons. I. classical morphology, J. Neurophysiol., 38 (1975) 53-71.

21 Negishi, K., Teranishi, T. and Kato, S., New dopaminergic and idoleamine-accumulating cells in the growth zone of goldfish retinas after neurotoxic destruction, Science, 216 (1982) 747-749.

22 Sargent, P.B., The number of synaptic boutons terminating on Xenopus cardiac ganglion cells is directly correlated with cell size, J. Physiol. (Lond.), 343 (1983) 85-104.

23 Sharma, S.C. and Ungar, F., Histogenesis of the goldfish retina, J. Comp. Neurol., 191 (1980) 373-382.

24 Teranishi, T., Negishi, K. and Kato, S., Functional and morphological correlates of amacrine cells in carp retina, Neuroscience, 20 (1987) 935-950.

25 Tauchi, M. and Masland, R.H., The shape and arrangement of the cholinergic neurons in the rabbit retina, Proc. R. Soc. Lond. Ser. B, 223 (1984) 415-431.

26 Tauchi, M. and Masland, R.H., Local order among the denrites of an amacrine cell population, $J$. Neurosci., 5 (1985) 2494-2501.

27 Tumosa, N., Eckenstein, F. and Stell, W.K., Immunocytochemical localization of putative cholinergic neurons in the goldfish retina, Neurosci. Lett., 48 (1984) 255-259.

28 Wagner, H.J. and Wagner, E., Amacrine cells in the retina of a teleost fish, the roach (Rutilus rutilis): Golgi study on differentiation and layering, Phil. Trans. R. Soc. Lond. Ser. $B, 321$ (1988) 263-324.

29 West, R.W. and Chernenko, G.A., Lack of synaptic reorganization in inner plexiform layer (IPL) of retina following ganglion cell degeneration, Experientia, 34 (1978) 1082-1083. 